\title{
EARTHQUAKE GROUND SHAKING HAZARD ASSESSMENT FOR THE LOWER HUTT AND PORIRUA AREAS, NEW ZEALAND
}

\author{
R. J. Van Dissen', J. J. Taber', W. R. Stephenson', \\ S. Sritheran', S. A. L. Read1, G. H. McVerry'1, \\ G. D. Dellow ${ }^{1}$, P. R. Barker²
}

\begin{abstract}
SUMMARY
Geographic variations in strong ground shaking expected during damaging earthquakes impacting on the Lower Hutt and Porirua areas are identified and quantified. Four ground shaking hazard zones have been mapped in the Lower Hutt area, and three in Porirua, based on geological, weak motion, and strong motion inputs. These hazard zones are graded from 1 to 5 . In general, Zone 5 areas are subject to the greatest hazard, and Zone 1 areas the least. In Lower Hutt, zones 3 and 4 are not differentiated and are referred to as Zone 3-4. The five-fold classification is used to indicate the range of relative response.

Zone 1 areas are underlain by bedrock. Zone 2 areas are typically underlain by compact alluvial and fan gravel. Zone 3-4 is underlain, to a depth of $20 \mathrm{~m}$, by interfingered layers of flexible (soft) sediment (fine sand, silt, clay, peat), and compact gravel and sand. Zone 5 is directly underlain by more than $10 \mathrm{~m}$ of flexible sediment with shear wave velocities in the order of $200 \mathrm{~m} / \mathrm{s}$ or less.

The response of each zone is assessed for two earthquake scenarios. Scenario 1 is for a moderate to large, shallow, distant earthquake that results in regional Modified Mercalli intensity V-VI shaking on bedrock. Scenario 2 is for a large, local, but rarer, Wellington fault earthquake. The response characterisation for each zone comprises: expected Modified Mercalli intensity; peak horizontal ground acceleration; duration of strong shaking; and amplification of ground motion with respect to bedrock, expressed as a Fourier spectral ratio, including the frequency range over which the most pronounced amplification occurs. In brief, high to very high ground motion amplifications are expected in Zone 5, relative to Zone 1, during a scenario 1 earthquake. Peak Fourier spectral ratios of 10-20 are expected in Zone 5, relative to Zone 1, and a difference of up to three, possibly four, MM intensity units is expected between the two zones. During a scenario 2 event, it is anticipated that the level of shaking throughout the Lower Hutt and Porirua region will increase markedly, relative to scenario 1, and the average difference in shaking between each zone will decrease.
\end{abstract}

\section{INTRODUCTION}

Seismic hazards pose a serious threat to the Wellington region. The region is located within the obliquely-convergent boundary between the Pacific and Australian tectonic plates. As a consequence, it is cut by several major active faults, and is not infrequently shaken by moderate to large earthquakes $[29,37]$ (Figs. $1 \& 2$ )

Strong ground shaking is the most pervasive earthquake hazard, and accounts, either directly or indirectly, for most of the damage, and consequent life loss, resulting from an earthquake.

\footnotetext{
${ }^{1}$ Institute of Geological \& Nuclear Sciences

${ }^{2}$ Landcare Research

${ }^{3}$ Victoria University of Wellington
}

Local geological deposits are well known for their ability to influence the level of shaking a site experiences during an earthquake. Following the great San Francisco earthquake of 1906, H.O. Wood noted that damage in the city "... depended chiefly on the geologic character of the ground. Where the surface was of solid rock, the shock produced little damage; whereas upon made ground [man-made fill] great violence was manifested..." [38]. In general, sites underlain by softer, "flexible" material experience greater shaking than nearby sites underlain by firmer, "stiff" material. Recent earthquakes affecting Mexico City, Leninakan, San Francisco, and Newcastle serve to illustrate this point, and underscore the important role that local geological conditions can have in influencing property damage and life loss during earthquakes $[26,7,35,25]$. 


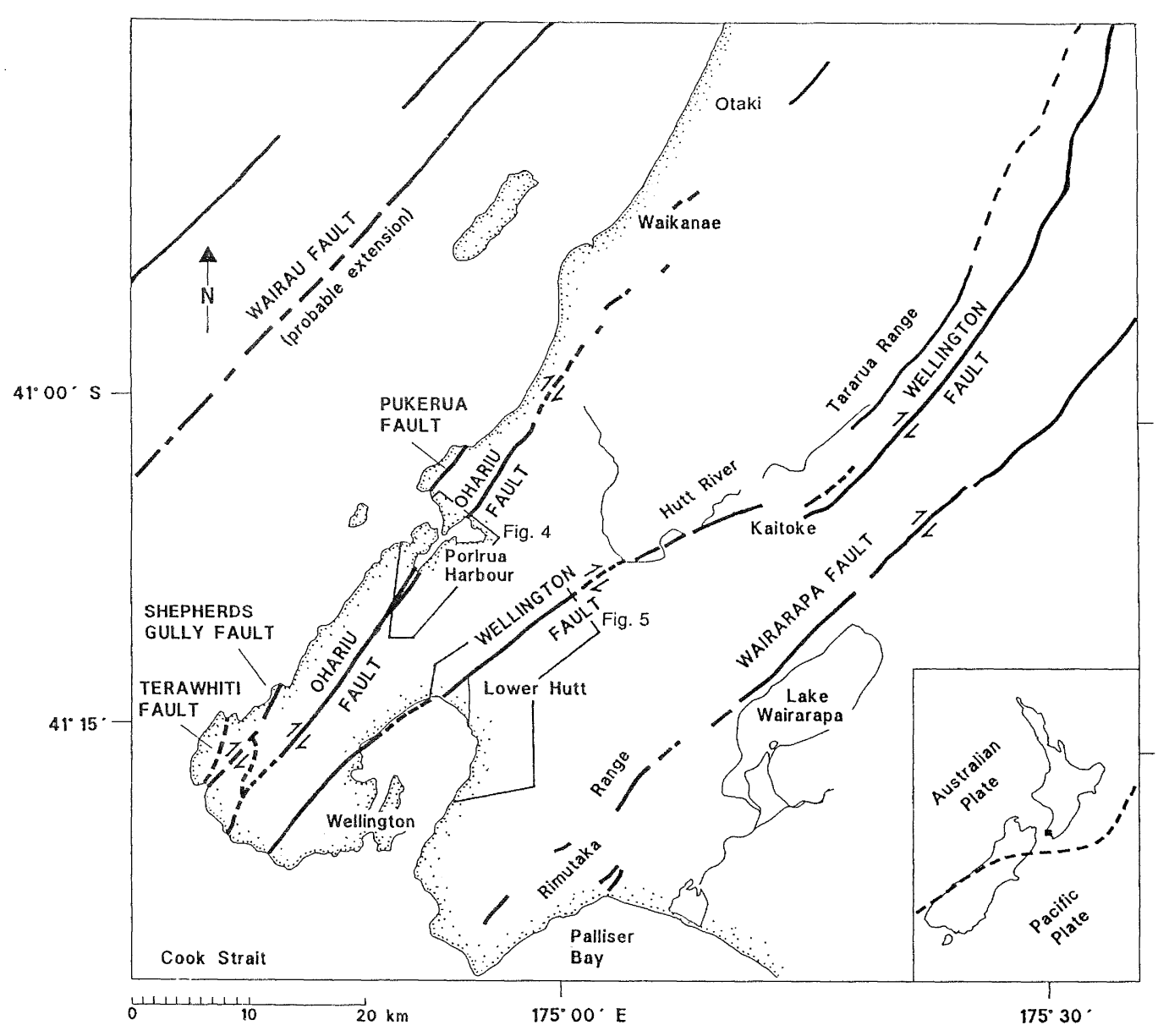

Figure 1. Active faults in the Wellington region. In addition to the faults shown, the subduction thrust between the Pacific plate and the overriding Australian plate is located $20-30 \mathrm{~km}$ beneath the Lower Hutt and Porirua areas.

Near-surface geological deposits in the Lower Hutt and Porirua areas range from strong rock to thick alluvial gravel to soft finegrained sediment. If areas of increased shaking hazard can be identified, then the potential exists, usually through land use control (by means of zoning), building codes, and/or retrofit strengthening, to reduce the vulnerability of the community to earthquake shaking. In 1990, the Wellington Regional Council commissioned the Institute of Geological \& Nuclear Sciences (then part of the Department of Scientific \& Industrial Research) to undertake an earthquake ground shaking hazard assessment for the Lower Hutt and Porirua areas. The individual data sets incorporated into this assessment are presented in detail in the accompanying papers in this volume and include: geological mapping, penetrometer probing, shear wave velocity measurements, and weak motion and strong motion earthquake records. Dellow et al. [10] maps and describes the distribution of the geological materials in the Porirua and Lower Hutt areas. Stephenson \& Barker [32] quantify the properties of the "weaker" materials using 12 cone and 3 seismic-cone penetrometer probings in Porirua, and 24 cone and 7 seismic-cone penetrometer probings in Lower Hutt (including Wainuiomata and Eastbourne). Taber \& Smith [33], using weak-motion earthquakes, measure the shaking response of a representative suite of geological materials at 12 sites in Porirua and 23 sites in the Lower Hutt area. Sritharan \& McVerry [30] also assess the microzoning effects in the Lower Hutt Valley using records from a strong motion accelerograph array; their seven sites range from bedrock to deep sediment (Fig. 3).

This paper presents a ground shaking hazard zonation for the Lower Hutt and Porirua areas that accounts for geographic variations in strong ground shaking resulting from near-surface geological ground conditions. The paper draws primarily from the work presented in the accompanying papers, and begins by summarizing their results pertaining to the spatial distribution of the geological materials in Porirua and Lower Hutt, the nearsurface shear wave velocities of these materials, and the measured response of these materials to non-damaging earthquake shaking. Based on this information, the geological materials are grouped into Ground Shaking Hazard Zones according to their relative ability to amplify ground shaking. The anticipated response of each zone is then characterized for damaging levels of shaking using a number of ground motion parameters, including: Modified Mercalli intensity, peak horizontal ground acceleration, duration of strong shaking, and Fourier spectral ratio. 


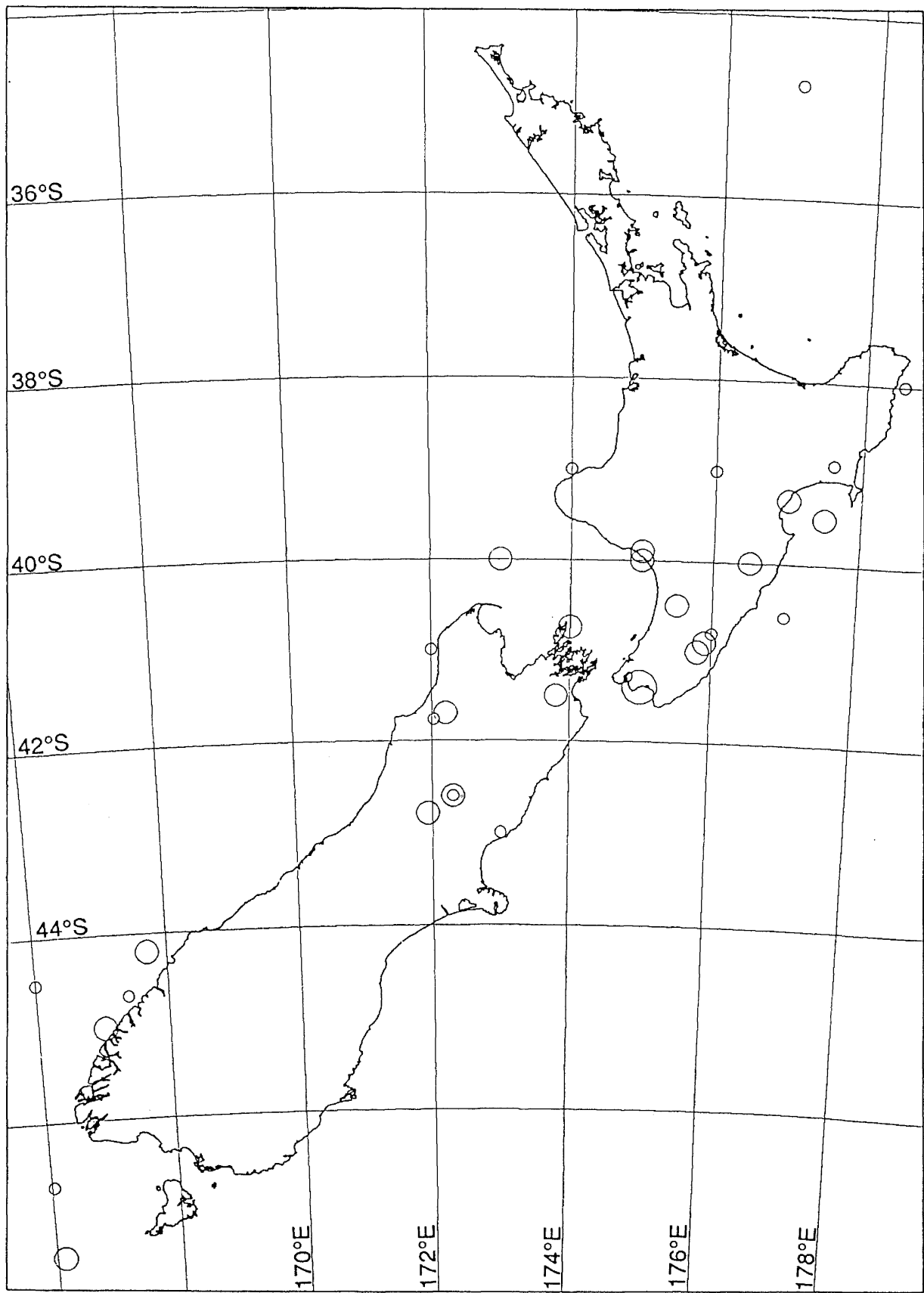

$1840-1992$

Figure 2. Epicentres of shallow earthquakes of magnitude 6.5 and greater since 1840 . Locations and magnitudes from New Zealand Seismological Observatory [23]. Size of circle indicates relative magnitude: small circle, $M$ 6.5-6.9; medium circle, $M$ 7.0-7.9; large circle, $M>8.0$. 


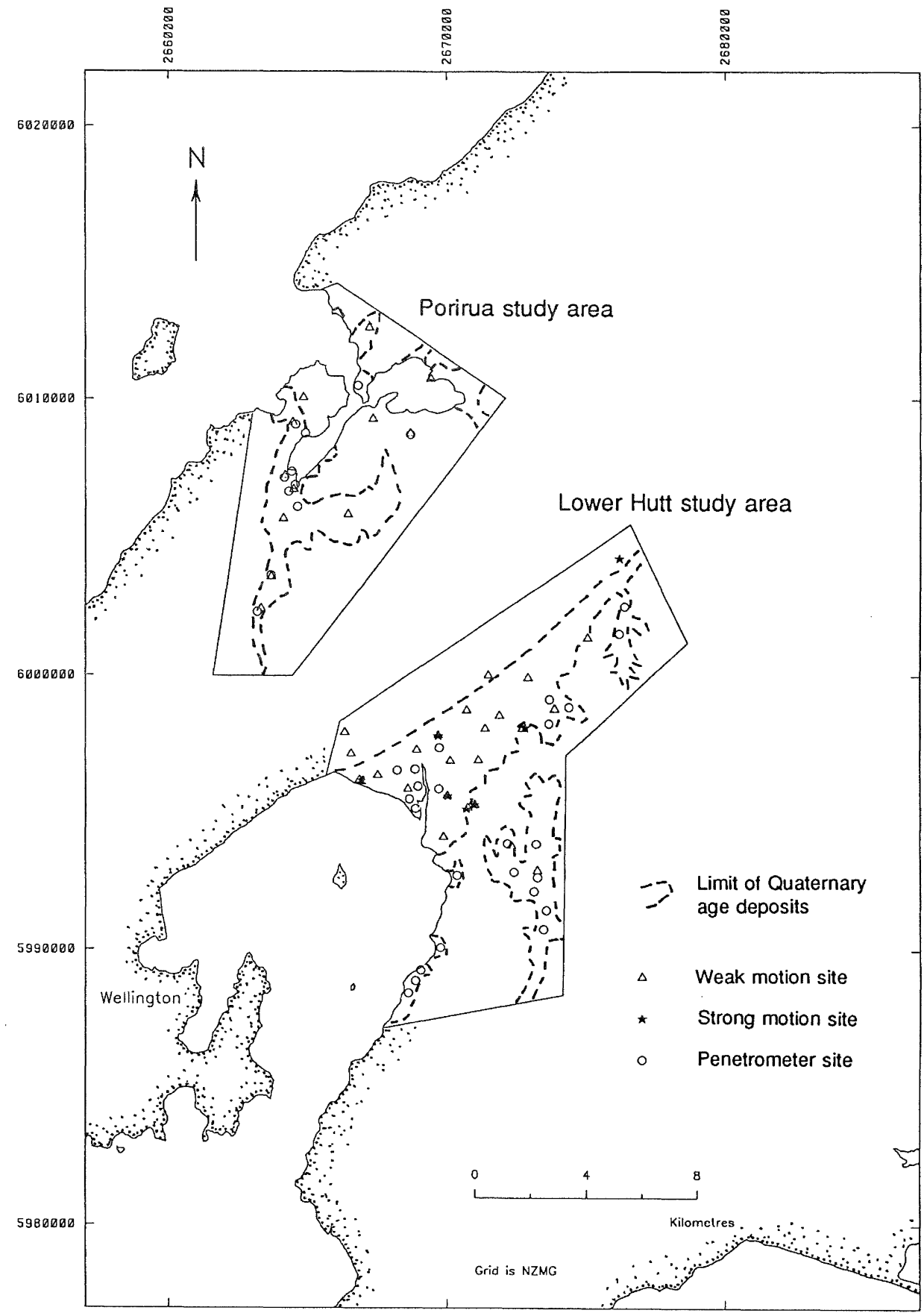

Figure 3. Study area layout, showing locations of weakmotion [33], strong-motion [30], and some penetrometer [32] sites. 


\section{IDENTIFICATION OF GROUND SHAKING HAZARD ZONES}

Geological, weak-motion, and strong-motion data sets are used to characterize the shaking response of the geological materials in the Porirua and Lower Hutt areas, and to group these materials into hazard zones according to relative shaking hazard.

\section{Porirua Zonation}

A "hazardous" thickness of flexible ${ }^{1}$ sediment is mapped in the Porirua Basin $[10,32]$. In the southern part of the basin, these sediments have shear wave velocities in the order of $110 \mathrm{~m} / \mathrm{s}$, and a maximum thickness of c. $15 \mathrm{~m}$. Three of the 12 seismograph sites of Taber \& Smith [33] showed greatly increased levels of shaking, two of which were flexible sediment sites, while the third was just outside of the mapped boundary. The recorded ground motions at these sites, expressed as the peak value of the averaged Fourier spectral ratios (Fsr), are 10-20 times stronger than those of the nearby reference bedrock site. The maximum amplification occurs over a narrow frequency band between $1-3 \mathrm{~Hz}$. The frequency and approximate amplification were as modeled by Stephenson \& Barker [32]. Spectral ratios of $\mathrm{Fsr}=10-20$ have also been measured for flexible sediment sites in Wainuiomata and the Lower Hutt Valley (see below).

Taber \& Smith [33] also measured the ground response on bedrock sites, including sites where bedrock is overlain by less than $10 \mathrm{~m}$ of deeply weathered gravel and loess. With the exception of one site, the spectral ratios for bedrock sites varied from no amplification to factors of about 3 relative to the reference bedrock site. This is consistent with results from the Lower Hutt area (see below). The exception was a site on a small topographic ridge at Whitby which showed a spectral ratio of nearly 10 at $5.5 \mathrm{~Hz}$. The amplification at this site could in part be due to topographic effects since spectral ratios of up to 8 have been recorded at hard rock ridge-crest sites [34]. Cone penetrometer results discount the possibility of a significant thickness of soft sediment near this site [32].

Dellow et al. [10] shows the distribution of near-surface compact gravel and sand deposits (eolian, alluvial and marine) in the Porirua area, including the extremely weak sandstone at Titahi Bay. Stephenson \& Barker [32] present cone penetrometer results from sites underlain by these deposits. The one seismograph sited on compact gravel/sand shows an amplification of Fsr $=5$ [33], similar to amplifications measured on like materials in the Lower Hutt area (see below).

1 The word flexible appears in the New Zealand building code (NZS 4203:1984) as flexible subsoil and applies to low strength cohesive soils (average undrained shear strength < $50-200 \mathrm{kPa}$ ) and cohesionless sands and gravels. In this paper we retain the usage of the word flexible, and define the term flexible sediment to mean low velocity sediment. That is, sedimentary material with shear wave velocities in the order of $200 \mathrm{~m} / \mathrm{s}$ or less. Typically, though not exclusively, these materials are loose or soft, medium- to fine-grained engineering soils (sand, silt, clay, peat).
Based on the distribution of geological materials in Porirua and the measured and modeled response of these materials to seismic waves, the Porirua area is mapped into three Ground Shaking Hazard Zones (Fig. 4). Zone 1 is characterized by areas underlain by "stiff" geological material (bedrock), and little if any amplification of seismic waves. However, localised yet potentially significant topographic amplifications are possible. Zone 2 is characterized by areas underlain by more than $10 \mathrm{~m}$ of compact gravel/sand, and low to moderate amplification of ground motion relative to bedrock. Areas underlain by a greater than $10 \mathrm{~m}$ thickness of flexible sediment show greatly amplified shaking, relative to bedrock, and are mapped as Zone 5 .

\section{LOWER HUTT ZONATION}

\section{Wainuiomata}

The highest spectral amplifications recorded in the Lower Hutt area, Fsr $=16-18$, are from two sediment sites in Wainuiomata [33]. Both sites are underlain by more than $10 \mathrm{~m}$ of soft sediment with shear wave velocities in the order of $90-150 \mathrm{~m} / \mathrm{s}$ $[10,32]$. The site underlain by the greatest total thickness of sediment (about $60 \mathrm{~m}$ ) exhibits a broad band frequency response over $0.5-3 \mathrm{~Hz}$, with a peak near $1 \mathrm{~Hz}$ [33]. The limited number of records available for this site from the strong motion array show strong amplification at about $0.8 \mathrm{~Hz}$ [30]. This peak is also accurately modeled by Stephenson \& Barker [32] on the basis of the upper $30 \mathrm{~m}$ of more flexible material. The site underlain by a lesser thickness of sediment exhibits a narrow frequency response at $2 \mathrm{~Hz}$. Areas underlain by flexible sediment in Wainuiomata are mapped as Zone 5 on the Ground Shaking Hazard Map (Fig. 5).

Areas in Wainuiomata underlain by bedrock, or less than $10 \mathrm{~m}$ of weathered gravel and loess are characterized as "stiff" sites. These sites, as for similar sites with measured ground motions in Porirua and the Lower Hutt Valley, are expected to experience little if any amplification of ground shaking, and are mapped as Zone 1 on the Ground Shaking Hazard Map (Fig 5).

As measured in the Lower Hutt Valley and Porirua, sites in Wainuiomata underlain by a greater than $10 \mathrm{~m}$ thickness of near-surface dense, compact, gravel are expected to experience low to moderate amplification of ground shaking relative to bedrock, and are mapped as Zone 2 on the Ground Shaking Hazard Map. In Wainuiomata, fan gravels interfinger with flexible sediment along the valley sides. Where these deposits comprise a major portion of the material at depth, they are mapped as Zone 2.

\section{Eastbourne}

The distribution of geological materials in Eastbourne (Point Howard to Point Arthur) is poorly constrained [10]. Five cone penetrometer tests were carried out to locate possible deposits of flexible sediment [32]. No significant soft or weak layers were identified below about three metres depth; all probes reached refusal in dense sand or gravel, except at one site where probing was stopped in very stiff clayey silty sand. From these results, Stephenson \& Barker [32] conclude that the areas investigated in Eastbourne are not likely to greatly amplify earthquake shaking. Based on this conclusion, the non-bedrock areas of Eastbourne are mapped as Zone 2 (Fig. 5), and are expected to only slightly amplify ground shaking. The bedrock areas of Eastbourne are mapped as Zone 1. 
GROUND SHAKING HAZARD MAP

FOR THE PORIRUA AREA

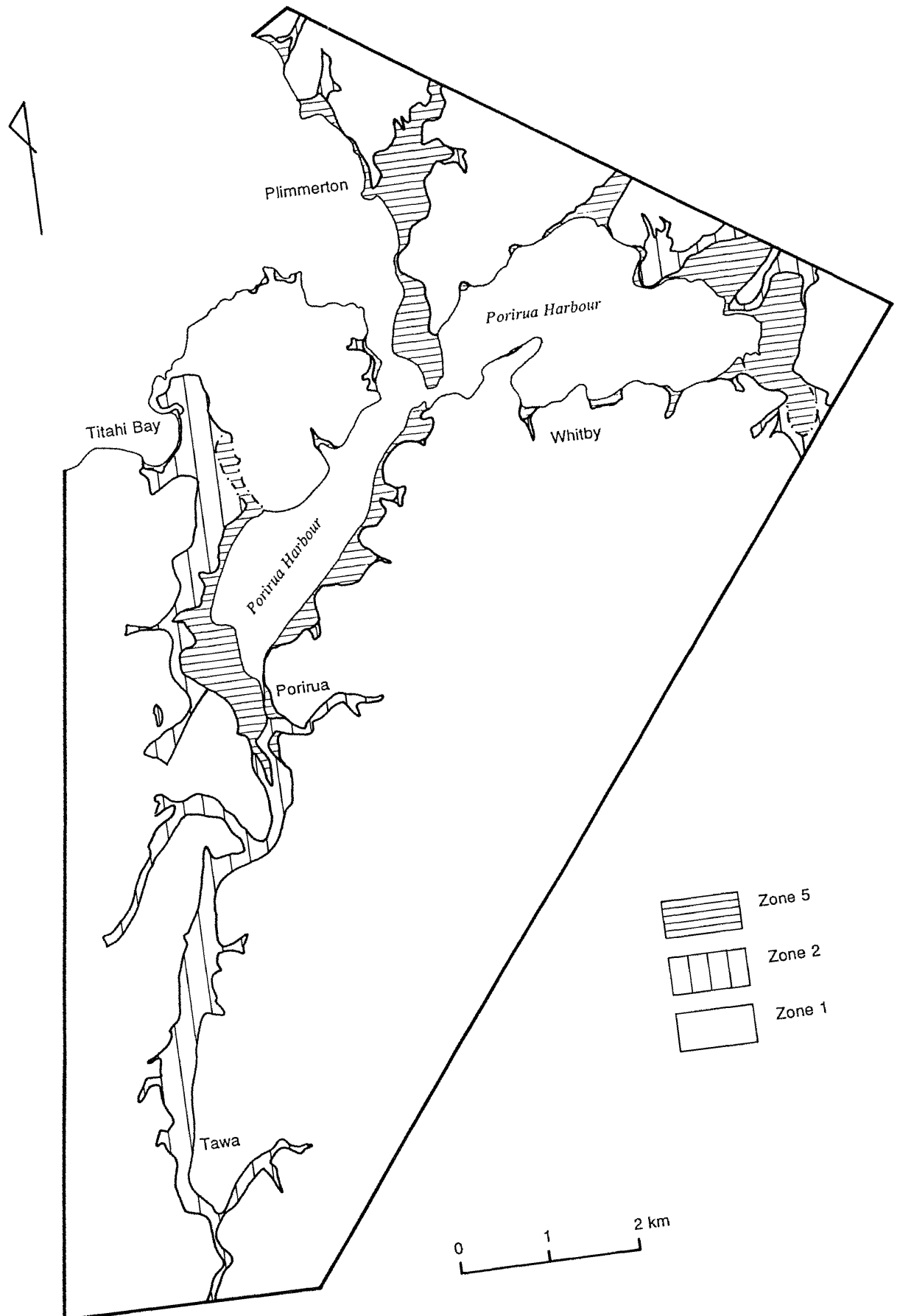

Figure 4. Ground shaking hazard map for the Porirua area. 


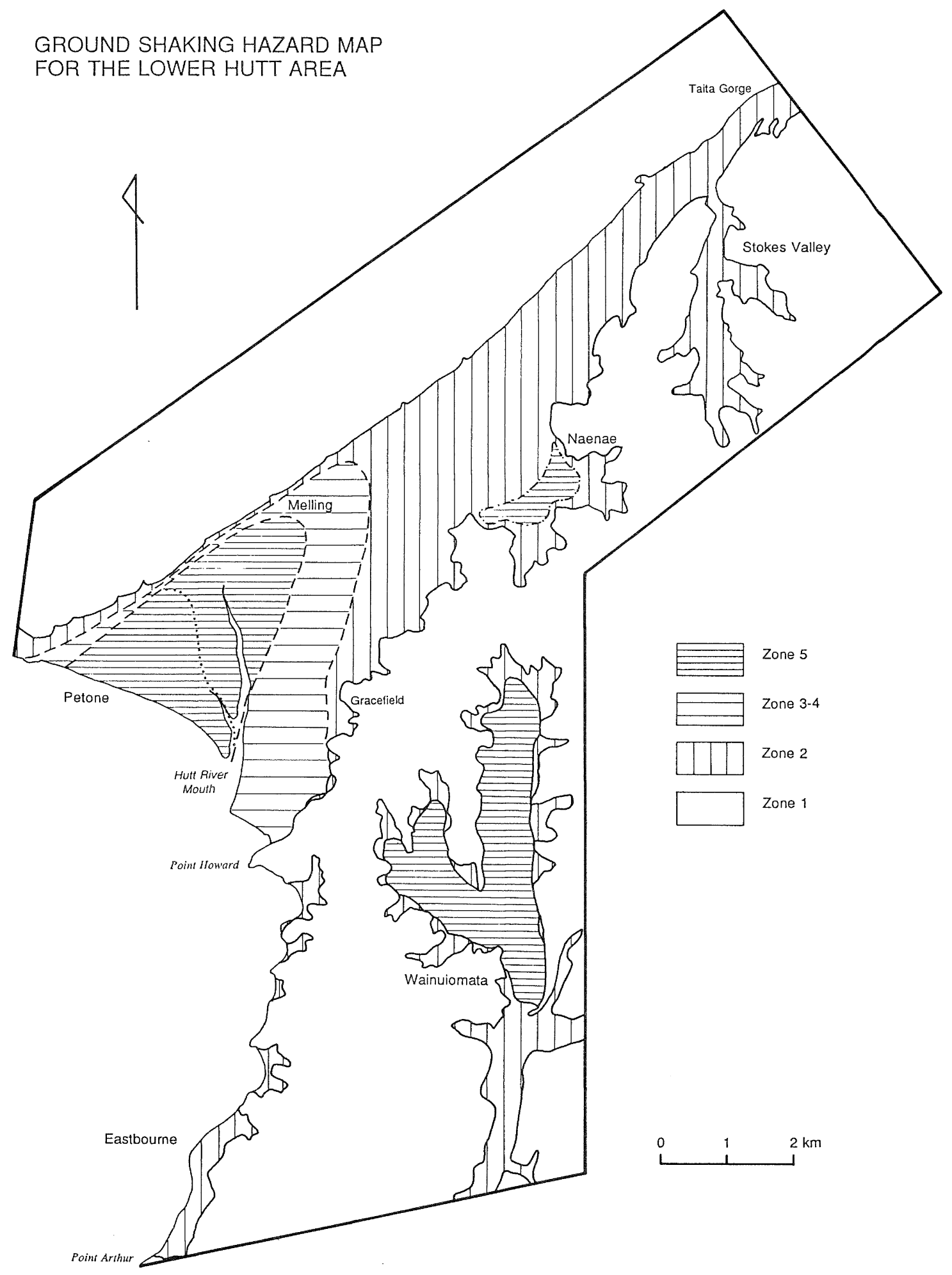

Figure 5. Ground shaking hazard map for the Lower Hutt area. 


\section{Lower Hutt Valley}

In the Lower Hutt Valley there is both a general increase in total sediment thickness and thickness of near-surface soft sediment down valley and across valley (Taita gorge to Petone, and from Gracefield to Petone) [10].

Five weak-motion stations of Taber \& Smith [33] were sited on bedrock, or deeply weathered gravel and loess underlain by bedrock. These stations show little if any amplification of microearthquake ground motions relative to the bedrock reference site; the spectral ratios are all less than Fsr $=4$. Three strong-motion instruments are sited on bedrock or deeply weathered bedrock. Compared to the response spectra of the reference site, one site shows slightly amplified ground motion, the other slightly attenuated motion [30]. In the Lower Hutt Valley areas underlain by bedrock, deeply weathered bedrock, or less than $10 \mathrm{~m}$ of deeply weathered gravel and loess are characterized as "stiff" sites. These sites exhibit very low to low amplification of earthquake motions, and are mapped as Zone 1 on the Ground Shaking Hazard Map (Fig. 5).

Much of the sediment in the Hutt Valley is composed of fine to coarse alluvial gravel interfingered with "weaker" layers of sand and silt. The total thickness of sediment increases from about $10-20 \mathrm{~m}$ near the Taita gorge to over $300 \mathrm{~m}$ at Petone. A significant thickness of near-surface flexible sediment is found southwest from about Melling. Its thickness also increases towards Petone [10]. Of the 16 weak-motion seismographs sited on the unconsolidated sediments in the Lower Hutt Valley, six had spectral ratios of less than about Fsr $=5$ [33]. These sites are all underlain by less than $200 \mathrm{~m}$ of gravel, and some sites are underlain by as little as $10 \mathrm{~m}$ of gravel. Also, none of the six sites are underlain by more than $5 \mathrm{~m}$ of near-surface flexible sediment. Areas with the above characteristics are mapped in the Lower Hutt Valley as Zone 2 on the Ground Shaking Hazard Map. The near five-fold amplification of the Zone 2 site in Porirua is consistent with the response of the Zone 2 sites in Lower Hutt. The strong motion instrument sited within Zone 2 shows an intermediate response compared to bedrock sites, and sites located in the deepest part of the valley where the strongest motions are recorded [30].

The highest amplifications recorded by Taber \& Smith [33] in the Lower Hutt Valley are at Petone where total sediment thickness, and thickness of near-surface soft sediment are at their maximum. Here, two sites have average peak spectral ratios of $\mathrm{Fsr}=12-15$, relative to the reference bedrock site. For sites near the Hutt River, and further northeast and east from Petone, averaged spectral ratios are less than 8 . Sites in Porirua and Wainuiomata that exhibit spectral ratios of greater than Fsr $=10$ are mapped as Zone 5. This implies that the Zone 5 boundary in the Lower Hutt Valley should be located southwest of the Hutt River, the dotted line on Ground Shaking Hazard Map (Fig. 5). However, the few available records from the strong motion array suggest that the long period response measured at the Petone site is similar to that measured at the central Lower Hutt site [30], though the short period motions at the two sites are different. This could suggest that the northeastern extent of Zone 5 should include central Lower Hutt. Where differing interpre-tations arise, we adopt, for this study, a conservative interpretation. Thus, central Lower Hutt is included in Zone 5. In doing so, the uncertainty regarding the northeastern extent on the Zone 5 boundary is acknowledged. Additional work is needed to confidently locate this boundary, whether this be northeast of central Lower Hutt or southwest of the Hutt River.
A spectral ratio of near 15 is recorded for a site in Naenae [33]. This site corresponds to an area of locally thick $(10-20 \mathrm{~m})$ soft sediment, and is mapped as Zone 5 .

The general down-valley increase in sediment thickness in the Lower Hutt Valley is reflected in the measured ground motions as a gradual down-valley increase in shaking [30,33]. The thickness of the top flexible layer varies in a manner similar to that of the total sediment [10], and whether the measured increase in shaking is due to the top layer or to the total sediment is yet to be resolved. There is no distinct boundary in Lower Hutt between sites that show low to moderate amplifications of ground shaking (Zone 2), and sites that exhibit high to very high amplifications (Zone 5). The transitional area between Zones 2 and 5 is mapped as Zone 3-4. The 3-4 distinction is chosen to highlight the transitional character of this zone, and to emphasize the greater shaking measured, and expected, in Zone 5 relative to that in Zones 1 and 2.

\section{Geological Description of Hazard Zones}

Three Ground Shaking Hazard Zones are mapped in Porirua, and four in Lower Hutt, based primarily on relationships between the level of ground motion amplification measured during non-damaging earthquakes and the distribution of geological materials in these areas. Descriptions of the materials that typify each hazard zone are summarized below.

Zone 1: Moderately strong to very strong sandstone and argillite (collectively referred to as greywacke bedrock). Includes areas where completely weathered, very weak greywacke bedrock is exposed at the surface (strength increases rapidly with depth), and where bedrock is overlain by less than $10 \mathrm{~m}$ of deeply weathered gravel and loess, or well engineered fill.

Zone 2: $\quad$ Alluvial gravel and fan alluvium; compact fine to coarse gravel, up to $200 \mathrm{~m}$ thick, interfingered with beds and lenses of finer grained sediment (sand, silt, clay, and peat) usually less than $5 \mathrm{~m}$ thick. The coarser sediment typically has moderate to high "Standard Penetration Test (SPT)" values $(\mathrm{N}=20->60)$. At Titahi Bay this zone includes $10-20 \mathrm{~m}$ thickness of extremely weak silty sandstone with lenses of gravel, or 5-10 m thickness of windblown sand.

Zone 3-4: Up to $15 \mathrm{~m}$ of fine-grained sediment (fine sand, silt, clay, and peat) within the top $20 \mathrm{~m}$ or so of alluvial gravel, underlain by up to $250 \mathrm{~m}$ of alluvial gravel and finer grained sediment. The near-surface fine-grained sediment typically has low SPT values $(\mathrm{N}=<20)$, whereas the coarser consolidated sediment generally has moderate to high SPT values $(N=20$ $>60$ ).

Zone 5: Soft sediment (fine sand, silt, clay, and peat), greater than $10 \mathrm{~m}$ thick, at or very near the surface, underlain by bedrock or a variable thickness of gravel and other finer grained sediment. Near-surface sediment in Zone 5 is characterized by low shear wave velocities; shear wave velocities for the upper 10-30 m of Zone 5 sediment at Lower Hutt, Wainuiomata, and Porirua are in the order of $175 \mathrm{~m} / \mathrm{s}, 90-150 \mathrm{~m} / \mathrm{s}$, and $110 \mathrm{~m} / \mathrm{s}$ respectively.

\section{ANTICIPATED GROUND MOTIONS}

The primary aim of this project was to zone the Lower Hutt and Porirua areas according to relative ground shaking hazard. Figures 4 and 5 summarize this zonation, with ground shaking 
hazard increasing from Zone 1 to Zone 5. However, quantification of the shaking anticipated in each zone during damaging earthquakes is needed if these maps are to offer the widest applicability and greatest use to both planner and engineer.

\section{Earthquake scenarios}

At the beginning of this study, it was recognised that no single earthquake scenario adequately describes the potential ground shaking hazard facing the Lower Hutt and Porirua areas. A large local earthquake will certainly be devastating, yet significant localized damage is also expected from large, more frequent, distant earthquakes. Geographic variations in ground shaking are thus assessed for two distinct earthquake scenarios.

Scenario $\mathbf{1}$ is for a large, distant, shallow earthquake that produces MM V-VI shaking intensities in bedrock over the Wellington region. It is expected that this type of earthquake will produce large variations in ground response, that is, a great difference between the shaking of the best areas and the worst [31]. This scenario implies little damage to structures founded on the best sites, yet significant damage to certain structures on the worst. An example of such an event would be a M 7 earthquake centred about $100 \mathrm{~km}$ from the study area at a depth of $15-30 \mathrm{~km}$, perhaps similar to the 1942 south Wairarapa earthquake [16]. The 1848 Marlborough earthquake [12] would also have resulted in significant, and predictable, variations in ground response.

Smith \& Berryman [29] published estimates of the return time for various levels of MM intensity shaking at "average" sites in the Wellington region, and throughout New Zealand. These estimates have recently been revised, using the same model, but more realistic estimates of key model parameters; the result being a roughly $50 \%$ increase in the return time of a given level of shaking in the Wellington region [27]. Thus accounting for the expected one unit decrease in MM shaking between an "average" site and a bedrock site, the return time of MM VI or greater shaking at bedrock sites of low topographic relief in the Wellington region is about 32 years. This return time is based on the occurrence of both large earthquakes, and moderate sized local events. While some local events will result in MM VI on bedrock, these may not cause significant damage (e.g. the 1968 M 5.5 earthquake documented in the Wellington microzoning study [15]). 32 years is thus a minimum estimate for the return time of a scenario 1 event. A reasonable maximum estimate is about 100 years; the return time of MM VII or greater shaking at bedrock sites in the Wellington region.

Scenario 2 is for a large earthquake centred on the WellingtonHutt Valley segment of the Wellington fault. Rupture of this 75 $\mathrm{km}$ long segment is expected to be associated with a c. M 7.5 earthquake at a depth less than $30 \mathrm{~km}$, and up to $5 \mathrm{~m}$ of rightlateral and $1 \mathrm{~m}$ of vertical displacement at the ground surface [1]. This segment has a mean earthquake recurrence interval of about 600 years, and last ruptured $340-490$ years ago [36].

The shaking response of the Ground Shaking Hazard Zones (Zones 1 through 5) is assessed for the above two earthquake scenarios, and is expressed as a suite of ground motion parameters, comprising: expected Modified Mercalli intensity (MM); peak horizontal ground acceleration (pga); duration of strong shaking; and amplification of ground motion with respect to bedrock, expressed as a Fourier spectral ratio (Fsr), including the frequency range over which the greatest amplification occurs. All except the last parameter has been estimated using comparisons found in the published scientific and engineering literature.

The 1989 Loma Prieta earthquake is significant with respect to this study because of the recorded variations in ground motion related to local geological conditions, and because its magnitude is similar to that expected for the scenario 1 earthquake. Thus, the values calculated for the above ground motion parameters are often compared with those reported for the Loma Prieta event $[4,6,24]$.

\section{Modified Mercalli intensity (MM)}

Scenario 1: The scenario 1 earthquake will be of sufficient duration and contain sufficient long period energy to allow strong long-period response to develop at deeper sediment sites. The shallow focal depth will allow strong surface wave effects, and the distance will ensure a long duration of strong shaking. The result is a marked difference between the shaking of the "worst" sediment site and the "best" rock site. It is not uncommon during an earthquake to have a spread of three to four units of MM intensity separating the response of the "best" site from the response of a nearby "worst" site $[8,13,22,24]$. A difference of up to three, possibly four, MM units is thus expected between the response of Zone 1 and Zone 5 . The response of Zones 2 and 3-4 is expected to be slightly stronger than Zone 1, comparable to estimates made by Grant-Taylor et al. [15] in their microzoning study of Wellington.

In terms of MM intensity the response of Zone 1 is expected to be MM V with some VI, Zone 2 is MM VI, Zone 3-4 is up to MM VI-VII, and Zone 5 is up to MM VIII-IX (Table 1).

Scenario 2: The effects of a scenario 2 event will be a marked increase in the shaking throughout the region, relative to scenario 1; a decrease in the average difference in shaking between Zone 1 and Zone 5; and an increase in the variability of shaking within each zone.

Another important factor influencing ground shaking for this event is distance from the earthquake source. In general, shaking decreases with increased distance away from the source. The entire Lower Hutt Valley is within $4 \mathrm{~km}$ of the Wellington fault; Wainuiomata and Porirua are about $6-11 \mathrm{~km}$ from the fault. Thus sites in Wainuiomata and Porirua are expected to shake less than similar sites in the Lower Hutt Valley.

Epicentral intensities for the 1989 Loma Prieta earthquake were MM VIII [24]; however, the Loma Prieta earthquake was smaller than the scenario 2 event (M 7.1 compared to 7.5). Epicentral intensities for similarly sized New Zealand earthquakes are MM IX, MM IX-X, and MM VIII-IX for the 1848 Marlborough, 1931 Hawkes Bay, and 1968 Inangahua earthquakes respectively $[12,28]$.

Using the above earthquakes as guides, MM IX is expected near the fault in Zone 1 (Table 1). Further from the fault, MM VIII is anticipated in Wainuiomata and Porirua for Zone 1. MM IX$\mathrm{X}$ is expected near the fault for Zone 2, MM VIII-XI further away in Wainuiomata and Porirua. The expected Zone 3-4 response, found only near the fault, is MM IX-X. Violent intensities, MM X-XI, are expected in Zone 5 both near the fault, and in Wainuiomata and Porirua. 
Table 1. Ground motion parameters, and values, for the Ground Shaking Hazard

Zones in the Lower Hutt and Porirua areas.

\begin{tabular}{|c|c|c|c|c|c|}
\hline \multicolumn{6}{|c|}{ SCENARIO 1} \\
\hline & Zones & $\begin{array}{c}\text { MM } \\
\text { Intensity }\end{array}$ & $\begin{array}{l}\text { Peak ground } \\
\text { accoleration } \\
\text { (g) }\end{array}$ & Duration & $\begin{array}{c}\text { Amplification of } \\
\text { ground motion } \\
\text { (Fsr) }\end{array}$ \\
\hline & 1 & $V-V I$ & $0.01-0.05$ & $<5$ sec & $1-3 \times$ \\
\hline & 2 & VI & $0.01-0.09$ & $2-3 \times$ & $2-5 \times$ \\
\hline & $3-4$ & VI-VII & $0.01-0.09$ & $2-3 \times$ & $5-10 \times$ \\
\hline & 5 & VIII-IX & $\begin{array}{c}<0.3, \\
\text { generally between } \\
0.02-0.14\end{array}$ & $>3 x$ & $10-20 \times$ \\
\hline \multicolumn{6}{|c|}{ SCENARIO 2} \\
\hline & Zone & $\begin{array}{c}\text { MM } \\
\text { Intensity }\end{array}$ & $\begin{array}{c}\text { Peak ground } \\
\text { acceleration } \\
\text { (g) }\end{array}$ & \multicolumn{2}{|r|}{ Duration } \\
\hline \multirow[t]{2}{*}{1} & near fault & IX & $0.5-0.8$ & \multirow{2}{*}{\multicolumn{2}{|c|}{$15-40 \mathrm{sec}$}} \\
\hline & $\begin{array}{l}\text { Porirua \& } \\
\text { Wainuiomata }\end{array}$ & VIII & $0.3-0.6$ & & \\
\hline \multirow[t]{2}{*}{2} & near fault & $1 x-x$ & $0.5-0.8$ & \multirow{2}{*}{\multicolumn{2}{|c|}{$1-2 \times$}} \\
\hline & $\begin{array}{l}\text { Porinua \& } \\
\text { Wainuiomata }\end{array}$ & VIII-IX & $0.3-0.6$ & & \\
\hline $3-4$ & & $1 x-x$ & $0.5-0.8$ & & $1-2 \times$ \\
\hline \multirow[t]{2}{*}{5} & near fault & \multirow{2}{*}{$x-x 1$} & $0.6-0.8$ & \multirow{2}{*}{\multicolumn{2}{|c|}{$<2 \times$}} \\
\hline & $\begin{array}{l}\text { Porirua \& } \\
\text { Wainuiomata }\end{array}$ & & & & \\
\hline
\end{tabular}

\section{Peak horizontal ground acceleration}

For both scenarios, peak horizontal ground acceleration is estimated based on comparisons with a number of attenuation relations $[9,14,18,19,20]$. Of these, the Japanese attenuation relation [14] appears to best fit the New Zealand data [11]. For scenario 1 , the range of peak ground accelerations presented below, and in Table 1, represent the mean minus one, and mean plus one standard deviation values predicted using Joyner \& Boore [20], and Fukushima \& Tanaka [14] respectively. The scenario 2 accelerations fall within the range of mean values predicted using the above relations $[9,14,18,19,20]$.
Scenario 1: Peak ground acceleration for Zone 1 is expected to be in the order of $0.01-0.05 \mathrm{~g}$. This compares to the $0.06 \mathrm{~g}$ recorded during the Loma Prieta earthquake at a hard rock site $95 \mathrm{~km}$ from the epicentre (Yerba Buena Island). Accelerations of 0.01-0.09 $\mathrm{g}$ are expected in Zones 2 and 3-4. For Zone 5 accelerations of $0.02-0.14 \mathrm{~g}$ are expected. In comparison with the Loma Prieta earthquake, accelerations in Zone 5 could be as high as $0.3 \mathrm{~g}$, based on the $0.29 \mathrm{~g}$ recorded $97 \mathrm{~km}$ from the epicentre on a "soil site" at Emeryville. 
Strong long period response is likely for the deepest sediment sites in the Lower Hutt Valley [30]. However, strong longperiod response is not well characterized by ground acceleration $[3,30]$. It is possible that accelerations at the "deep" sediment Zone 5 areas in the Lower Hutt Valley may be lower than accelerations at the "thin" sediment Zone 5 areas in, for example, Porirua. Additional work is however needed to verify this possibility; thus, all Zone 5 areas are given the same range of accelerations in Table 1 .

Scenario 2: The peak ground accelerations expected for scenario 2 are as follows: Zone $1,0.5-0.8 \mathrm{~g}$ in Lower Hutt Valley (near fault), 0.3-0.6 g in Porirua and Wainuiomata; Zone 2, 0.5-0.8 $\mathrm{g}$ in Lower Hutt Valley, 0.3-0.6 $\mathrm{g}$ in Porirua and Wainuiomata; Zone 3-4, 0.5-0.8 g; Zone 5, 0.6-0.8 g in Lower Hutt Valley, 0.5-0.8 g in Porirua and Wainuiomata.

\section{Duration of strong shaking}

In general, duration of shaking increases with decreasing stiffness of the underlying sediment. This has been observed for microearthquakes [33] and for larger damaging earthquakes [4]. In this paper, duration refers to the time between the first and last accelerations that exceed $0.05 \mathrm{~g}$.

Scenario 1: The expected duration of strong shaking in Zone 1 during a scenario 1 event is less than $5 \mathrm{sec}$ (Table 1). The expected increase in duration of shaking relative to bedrock is 2-3 times in Zones 2 and 3-4, and more than 3 times in Zone 5. These values are broadly consistent with the intensity based increases in duration reported in Krinitzsky \& Chang [21].

Scenario 2: Length and complexity of fault rupture are controlling factors regarding the duration of near-source ground shaking. The Loma Prieta earthquake produced about 10 seconds of strong shaking, resulting from a bilateral rupture of a roughly $40 \mathrm{~km}$ long fault plane [35]. Had the rupture been unilateral, that is, propagating from one end of the fault to the other, instead of bilateral, propagating from the centre of the fault to the ends, the shaking would have lasted much longer, perhaps up to about $20 \mathrm{sec}$. Rupture of the Wellington fault in scenario 2 is expected to be about twice as long as the fault rupture that produced the Loma Prieta earthquake. The duration of shaking for Zone 1 during scenario 2 is expected to be in the order of 15-40 sec, by comparison with the Loma Prieta event and depending on whether the rupture propagates bilaterally or unilaterally. This compares with the $30 \mathrm{sec}$ duration predicted for a M 7.5 earthquake using figure 27 in Hays [17]. The increase in duration, relative to Zone 1 , is 1-2 times for Zones 2 and 3-4, and $<2$ times for Zone 5 (Table 1).

\section{Fourier spectral ratios}

Taber \& Smith [33] measured the relative shaking response at 35 sites throughout the Porirua and Lower Hutt areas due to microearthquakes. Their results are expressed as peak values of averaged ratios of Fourier spectra of the seismograms. Spectral ratios vary from 1-3 for bedrock sites up to about 20 for flexible sediment sites.

Characteristic Fourier spectral ratios (Fsr) for each of the mapped hazard zones are as follows (Table 1): Zone 1, very low to low amplification of ground motion with Fsr less than 3; Zone 2, low to moderate amplification with $\mathrm{Fsr}=2-5$; Zone 3-4, moderate to high amplification with $\mathrm{Fsr}=5-10$; Zone 5, high to very high amplification with $\mathrm{Fsr}=10-20$.
Taber \& Smith [33] suggest that their results are not only useful for determining relative shaking, but also for identifying the frequencies over which this shaking will be most strongly amplified during certain earthquakes, specifically scenario 1 type events. This is supported by the findings of Borcherdt et al. [7] who concluded that the frequency of amplified shaking in Leninakan during aftershocks of the 1988 Armenian earthquake was the same as that of the larger damaging main shock, a $M$ 6.8 event about $35 \mathrm{~km}$ distant from Leninakan.

Ground motion amplification at most of the sites in Porirua and Lower Hutt occurs over a broad frequency band; however, some sites, particularly those in Zone 5, exhibit a narrow (resonant) frequency response. Site resonance is of most concern where man-made structures exist with natural periods that coincide with the resonant period band(s) of strong ground shaking. In general, Zone 5 sites in Porirua, Naenae, and Wainuiomata have peak amplifications within a narrow (less than $2 \mathrm{~Hz}$ wide) frequency band. The maximum occurs in the range from 1 to $2 \mathrm{~Hz}$. Zone 5 sites in the southern Lower Hutt Valley exhibit broad band amplifications with significant low frequency response.

Even though the ground motion amplifications measured in the Lower Hutt and Porirua areas were recorded during nondamaging earthquakes (low-strain shaking), it is significant to note that intensity maps prepared in the 1970's for the San Francisco Bay area, based on low-strain amplification, anticipated all of the areas that experienced high MM intensities during the 1989 Loma Prieta earthquake [2]. However, the level of amplification during even larger ground motions, that is, the level of shaking at near-source sites during large or great earthquakes is an unresolved question. An amplification of Fsr near 20 in Zone 5 is unlikely to persist during extreme motions because at high strain levels weak sediments behave in a nonlinear fashion, i.e. they lose strength and increase wave attenuation or damping. Nevertheless, variations in the nature of seismic response can still be expected from one zone to another during a scenario 2 event. High amplifications of small bedrock ground motions, such as the scenario 1 bedrock motions, mean that significant local damage in Zone 5 could result from an earthquake that would cause little or no damage in Zone 1. It is amplification of small bedrock ground motions that the reported spectral ratios best characterize, thus they are given only for scenario 1 .

\section{COMPARISONS WITH A RECENT CALIFORNIA ZONATION}

Borcherdt [2] takes advantage of the relatively complete geologic, geotechnical, and seismic data sets available for the San Francisco Bay area to develop empirical relationships regarding the shaking response characteristics of the wide spectrum of geological deposits in the area. The data sets include detailed geological maps, shear wave velocity logs, intensity data from the 1906 and 1989 earthquakes, and weak and strong motion records. The geological deposits of the San Francisco Bay area have many similarities with those encountered in the Lower Hutt and Porirua areas, ranging from strong rock to thick alluvium to soft fine-grained sediment.

Borcherdt [2] presents correlations among the near-surface geological materials present in the San Francisco Bay area; nearsurface shear-wave velocity measured for the upper $30 \mathrm{~m}$; amplification of ground motion, expressed as a ratio of average Fourier spectra for the frequency band $0.5-2.5 \mathrm{~Hz}$, measured 
Table 2. Grouping of geological materials in the San Francisco Bay area according to amplification capability, based on measured ground motion amplification, intensity incre-ment, physical properties, and geological characteristics. The relationship between this grouping and the Ground Shaking Hazard Zones in the Lower Hutt and Porirua areas is shown. After Table 2 of Borcherdt [2].

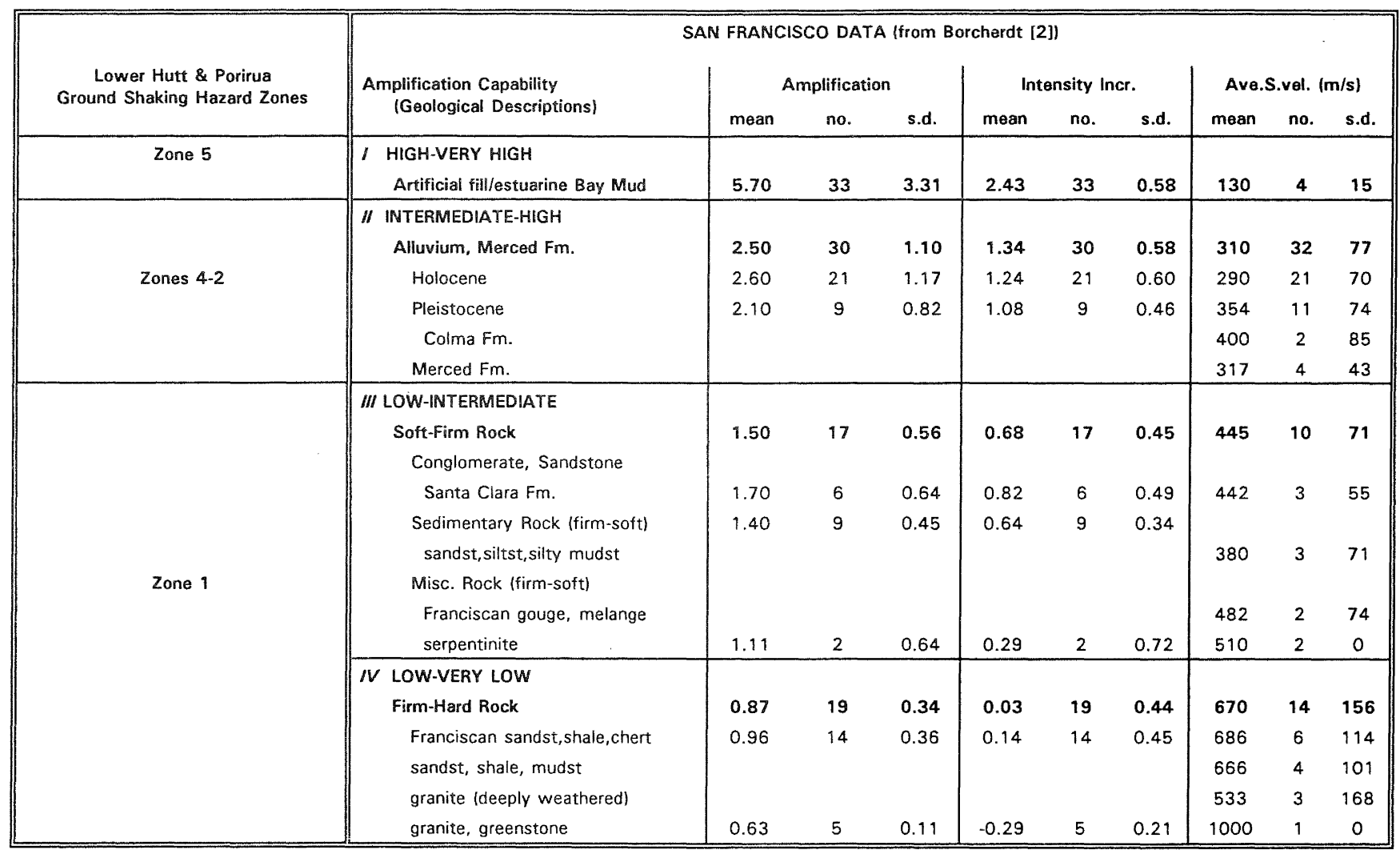

both during low-strain (non-damaging) shaking and the damaging Loma Prieta earthquake; and felt intensities for the great 1906 San Francisco earthquake. These correlations are summarized in Table 2, and Figures $6 \& 7$. Figures $6 \& 7$ show that mean amplifica-tion in terms of measured ground motions or felt earthquake intensity increases with decreasing near-surface shear wave velocity of the local geological material. Also shown on Figure 6 are characteristic shear wave velocities for typical near-surface geological materials present in the Porirua and Lower Hutt areas, and the correlation of these materials with the mapped Ground Shaking Hazard Zones.

The ground motion results summarized in this paper and those presented in Borcherdt [2] are highly comparable. Both studies show an increase in ground motion with decreasing stiffness of the near-surface deposit. With respect to potential amplification of earthquake ground motions, both studies show that the deposits of most concern are soft soils, or flexible sediment. During the 1989 Loma Prieta earthquake the areas located outside the immediate epicentral region that experienced intense damage were underlain by soft soil (flexible sediment). In the great 1906 San Francisco earthquake, sites underlain by these materials averaged 2-3 units greater intensity shaking compared to nearby sites underlain by strong rock. Typically these deposits are geologically young, unconsolidated, fine-grained materials (fine sand, silt, clay, and peat), often water saturated, with low shear-wave velocities (in the order of $200 \mathrm{~m} / \mathrm{s}$ or less). These materials have a high to very high amplification capability, and are mapped as Zone 5 in the Lower Hutt and Porirua areas. By the identification of such "hazardous" areas, potential exists to reduce the risk posed by strong ground shaking.

The ground shaking hazard maps for the Porirua and Lower Hutt areas (Figs. 4 \& 5) could also be called "amplification capability" maps, using the terminology of Borcherdt [2] and Borcherdt et al. [5]. It is a map that identifies zones according to their capability to amplify ground motion. 

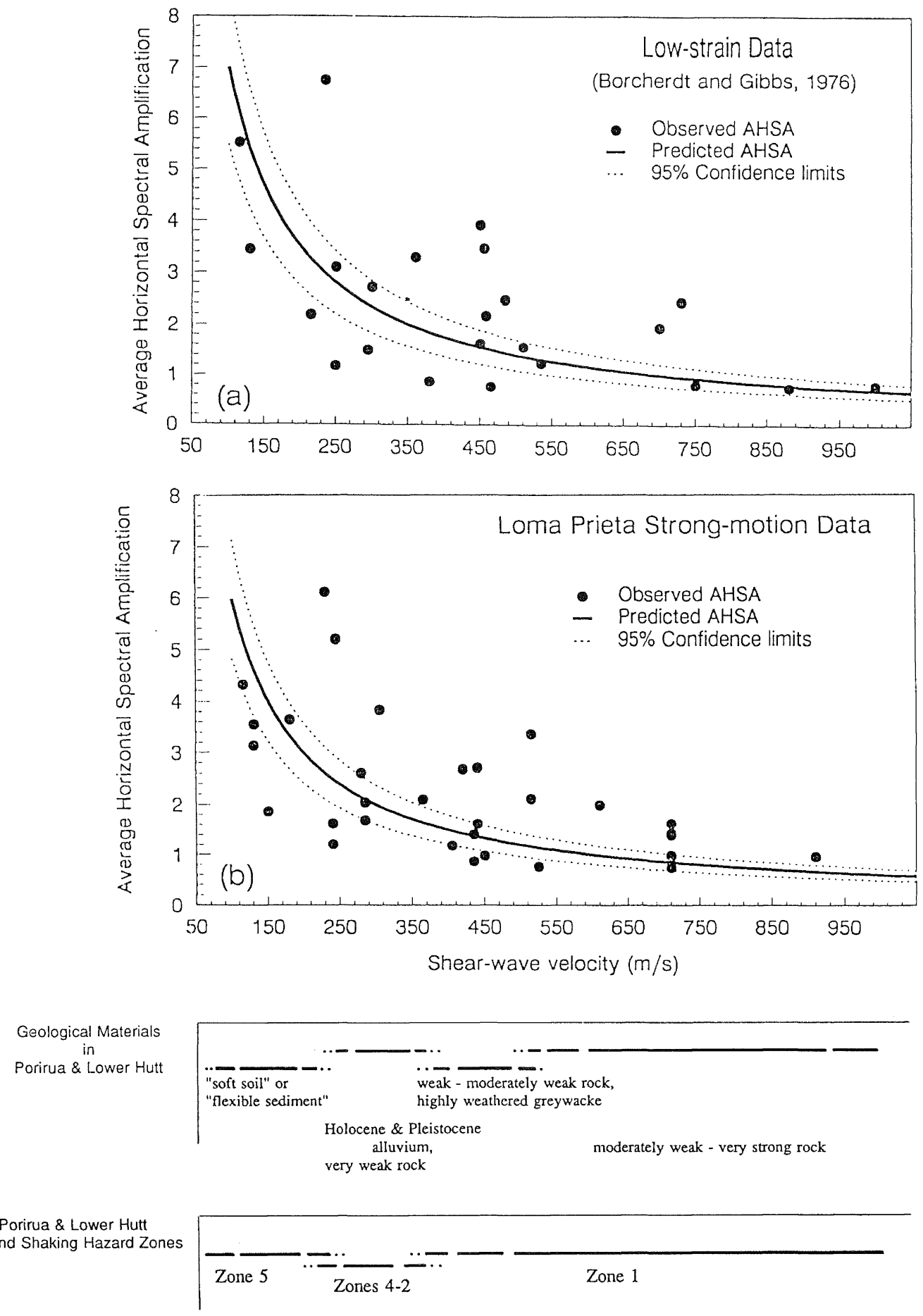

Figure 6. Average horizontal spectral amplification (AHSA) of ground shaking, plotted against near-surface shear wave velocity, measured in the San Francisco Bay area during both (a) low-strain shaking and (b) the Loma Prieta earthquake. AHSA is taken over the frequency band of 0.5$2.5 \mathrm{~Hz}$. Also shown are typical measured, and estimated, near-surface shear wave velocities for the geological materials in the Lower Hutt and Porirua areas, and corresponding Ground Shaking Hazard Zones. After Figure 5 of Borcherdt [2]. 


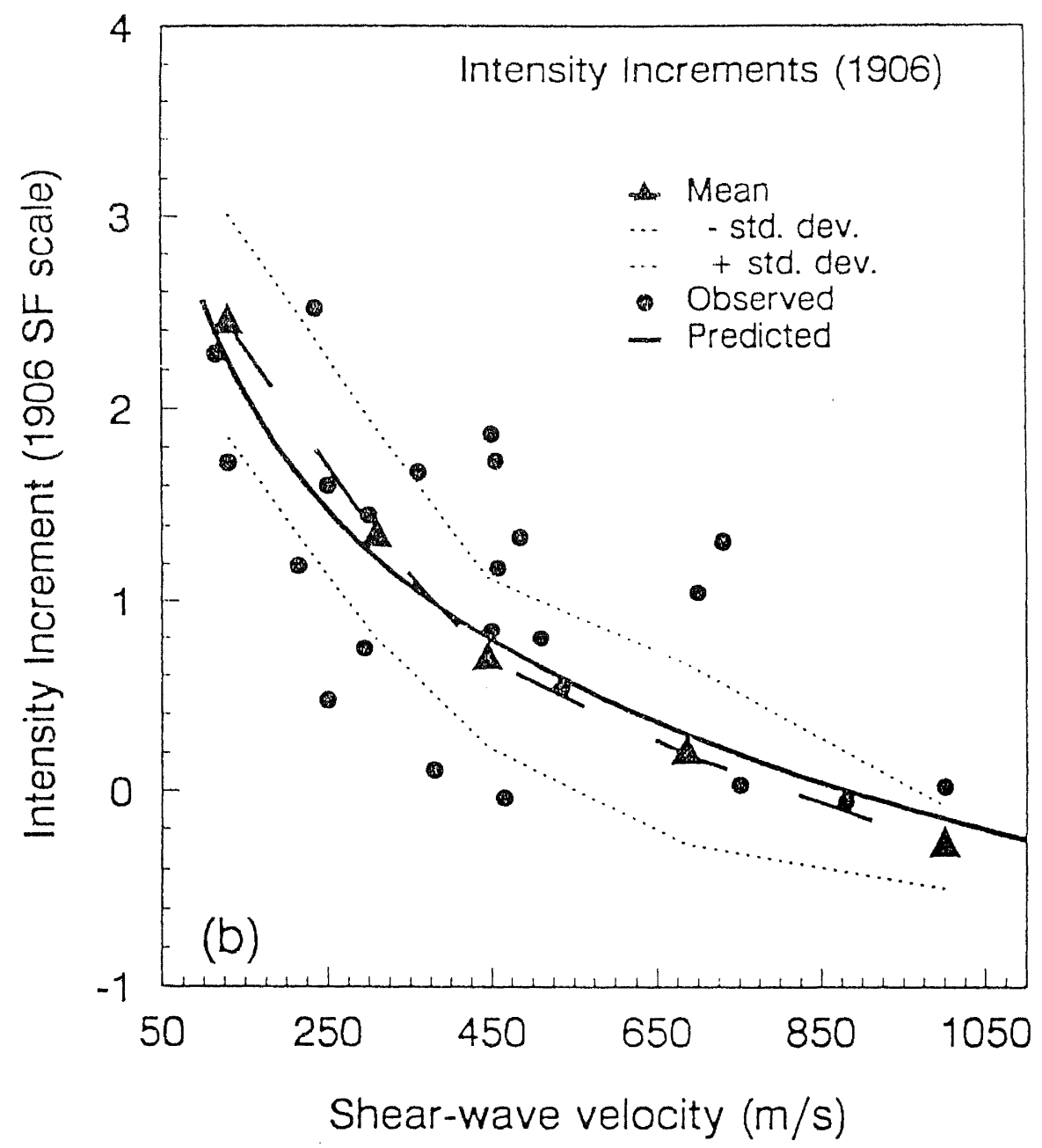

Porirua \& Lower Hutt Ground Shaking Hazard Zones

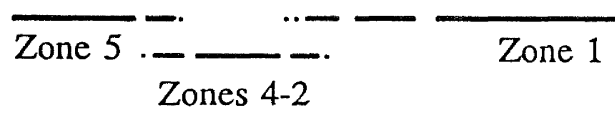

Figure 7. 1906 San Francisco earthquake intensity increments for individual sites in San Francisco, plotted against the near-surface shear wave velocity of the site. Also shown are representative correlations between near-surface shear wave velocity and the Ground Shaking Hazard Zones mapped in the Lower Hutt and Porirua areas. This plot, as well as Figure 6, shows that average ground motion amplification increases with decreasing near-surface shear wave velocity. * Note, an increment on the 1906 San Francisco intensity scale is approximately equal to an increment on the MM intensity scale, at the levels of shaking experienced in San Francisco during the great 1906 earthquake. After Figure 6 of Borcherdt [2]. 


\section{LIMITATIONS OF STUDY}

This study presents the first regional, multi-disciplinary assessment of the ground shaking hazard in the Lower Hutt and Porirua areas, and represents an important step towards reducing earthquake related damage and life-loss in these areas. Nevertheless, it is appropriate to discuss some of the important limitations of this study. In doing so, we hope to put our ground shaking hazard zonation into a more assessable context, and draw attention to areas where additional research will provide the greatest benefits towards defining the ground shaking hazard in the Lower Hutt and Porirua areas.

1) Within each Hazard Zone there are isolated occurrences of materials that may cause ground motions that are not typical of the Zone as a whole. In the western Hutt hills there are small terrace remnants, and local areas of deeply weathered bedrock. These have been included in Zone 1 , but it is possible their response could be closer to that of Zone 2 .

Much of what is mapped as Zone 2 in the Lower Hutt Valley is underlain by a thin near-surface layer of overbank silt, or organic-rich silt deposited in slackwater conditions. Usually these deposits are less than 5 $\mathrm{m}$ thick, and underlain by coarser alluvial gravels. However, locally they are greater than $10 \mathrm{~m}$ thick, and an extreme example is at Naenae. At these "thicker" localities a less favourable response is expected, relative to Zone 2.

The mapped fills in Porirua East [10] are placed on bedrock, and are included with Zone 1 . However, these fills are over $20 \mathrm{~m}$ thick in places, and may respond more like Zone 2.

In Eastbourne, the spacing of penetrometer probings does not preclude the existence of isolated pockets of flexible sediment. If thick enough, these sediments would respond less favourably than the general Zone 2 response expected for most of Eastbourne. Conversely, some areas mapped in Porirua as Zone 5 may not be underlain by enough sediment to cause high amplifications of ground motion. At these "thinner" sites a more favourable response may result.

2) High amplifications have been recorded at Titahi Bay and Naenae, but the distribution of the materials causing these amplifications is not well defined. The poorly resolved boundary around these Zone 5 areas is denoted as a dot-dash line on the Ground Shaking Hazard Map (Figs. 4 \& 5).

3) The Zone 5 and Zone 3-4 boundaries in the southern Lower Hutt Valley are gradational, most probably reflecting the gradual down-valley increase in both total sediment thickness and thickness of soft near-surface flexible sediment. These boundaries are marked on Figure 5 as dashed lines.

4) As noted in a previous section, the northeastern extent of Zone 5 in southern Lower Hutt is based on a conservative interpretation of the data obtained from the strong motion array [30]. However, the weak-motion amplifications presented in Taber \& Smith [33] suggest that the Zone 5 boundary should be located south of the Hutt River (the dotted line on Figure 5). The strong- motion site in central Lower Hutt, northeast of the Hutt River, shows the presence of long period peaks in some records. The possibility that these peaks may be strongly amplified during large magnitude damaging earthquakes is the primary reason why the Zone 5 boundary is located northeast of the Hutt River to include central Lower Hutt. Additional work is certainly needed to test this possibility, and to more confidently locate the boundary.

5) Amplification of ground motions due to topographic effects has not been addressed in this study. Though localized, these effects can nevertheless be pronounced. Spectral ratios of up to 8 have resulted from topographic amplifications at rock sites [34]. It is possible that the high amplification at a "stiff" site in Whitby is also in part the result of topographic effects.

6) Scenario 2 ground motion parameters are defined with less certainty. There is a world-wide lack of near-source ground motion data recorded during large earthquakes. Moreover, during a large local earthquake, near-source seismic wave propagation will be complex and nonuniform, and ground strains will be large enough to cause some sediments to exhibit non-linear response (attenuation of ground motions). These effects will tend to increase the variability of shaking within a zone, decrease the average difference in shaking between zones, and decrease the certainty with which expected ground motions can be characterized. Also, near-source ground motions for an earthquake associated with a long fault rupture, such as scenario 2, may be more correlated with proximity to local asperities along the fault rupture, rather than proximity to the fault itself.

\section{CONCLUSIONS}

Four Ground Shaking Hazard Zones have been identified in the Lower Hutt area, and three in Porirua (Figs. 4 \& 5). These zones are graded from 1 to 5 , with Zone 5 subject to the greatest hazard, and Zone 1 the least. The expected response of each of these zones is assessed for two earthquake scenarios and summarized in Table 1. High to very high ground motion amplifications are expected in Zone 5, relative to Zone 1, during distant, shallow, damaging earthquakes impacting on Lower Hutt and Porirua. Peak Fourier spectral ratios of 10-20 are expected in Zone 5, relative to Zone 1, and a difference of up to three, possibly four, MM intensity units is expected between the two zones. During large local earthquakes it is anticipated that the level of shaking throughout the region will increase markedly, and the average difference in shaking between each zone will decrease.

Areas underlain by a greater than $10 \mathrm{~m}$ thickness of soft flexible sediment are expected to strongly amplify earthquake ground motions. These areas are mapped as Zone 5. The high amplifications that characterize this Zone imply that significant local damage in Zone 5 could result from an earthquake that would cause little or no damage at a nearby "stiff" site (Zone 1).

Within Zone 5 , sites underlain by a relatively simple sequence of flexible sediment, such as a 10-30 m thickness over bedrock, tend to show high amplifications within a narrow frequency range; whereas sites underlain by a more complex sequence, such as more than $10 \mathrm{~m}$ of flexible sediment over some 
appreciable thickness of coarser sediment (greater than $50 \mathrm{~m}$ ), tend to show high amplifications over a broader frequency range. Any structure with a natural period within the range of measured amplified frequencies $[30,33]$ is potentially at greater risk relative to a nearby structure sited on similar materials but with a different natural period.

\section{ACKNOWLEDGMENTS}

This project was largely funded by the Wellington Regional Council; their support is gratefully acknowledged. Kelvin Berryman, Des Darby, Graeme Hancox, and Nick Perrin (Institute of Geological \& Nuclear Sciences) provided helpful reviews of drafts of this paper. Institute of Geological \& Nuclear Sciences contribution 17.

\section{REFERENCES}

1. Berryman, K.R. 1990, "Late Quaternary movement on the Wellington Fault in the Upper Hutt area, New Zealand", New Zealand Journal of Geology and Geophysics 33: 257-270.

2. Borcherdt, R.D. 1991, "On the observation, characterization, and predictive GIS mapping of strong ground shaking for seismic zonation: a case study in the San Francisco Bay region, California", In Proceedings, Pacific Conference on Earthquake Engineering. Auckland, New Zealand: v. 1. p. 1-24.

3. Borcherdt, R.D. 1985, "Predicting earthquake ground motion: an introduction", In Evaluating Earthquake Hazards in the Los Angeles Region - An Earth-Science Perspective. U.S. Geological Survey Professional Paper 1360: 93-99.

4. Borcherdt, R.D., Glassmoyer, G. 1992, "On the characteristics of local geology and their influence on ground motions generated by the Loma Prieta earthquake in the San Francisco Bay region, California", Bulletin of the Seismological Society of America 82: 603-641.

5. Borcherdt, R., Wentworth, C.M., Janssen, A., Fumal, T., Gibbs, J. 1991, "Methodology for predictive GIS mapping of special study zones for strong ground shaking in the San Francisco Bay region, CA", In Proceedings, Fourth International Conference on Seismic Zonation. Stanford, California: Vol. 3. p. 545-552.

6. Borcherdt, R.D., Glassmoyer, G. 1990, "Local geology and its influence on strong ground motion generated by the Loma Prieta earthquake of October 17, 1989", In Proceedings, Putting the Pieces Together, The Loma Prieta Earthquake One Year Later. San Francisco.

7. Borcherdt, R., Glassmoyer, G., Andrews, M., Cranswick, E. 1989, "Effects of site conditions on ground motion and damage", In Armenia Earthquake Reconnaissance report. Earthquake Spectra, special supplement: 23-42.

8. Borcherdt, R.D., Gibbs, J.F. 1976, "Effects of local geological conditions in the San Francisco Bay region on ground motions and the intensities of the 1906 earthquake", Bulletin Seismological Society of America 66: $465-500$.
9. Campbell, K.W. 1981, "Near-source attenuation of peak horizon-tal acceleration", Bulletin of the Seismological Society of America 71: 2039-2070.

10. Dellow, G.D., Read, S.A.L., Begg, J.G., Van Dissen, R.J., Perrin, N.D. 1992, "Distribution of geological materials in Lower Hutt, and Porirua, New Zealand: a component of a ground shaking hazard assessment", Bulletin of the New Zealand National Society for Earthquake Engineering (this volume).

11. Dowrick, D.J., Sritharan, S. 1992, "Attenuation of peak ground accelerations in some recent New Zealand earthquakes", Bulletin of the New Zealand National Society for Earthquake Engineering, Vol.25 No.4, pp

12. Eiby, G.A. 1980, "The Marlborough earthquakes of 1848", DSIR Bulletin 225.

13. Evernden, J.F., Thomson, J.M. 1988, "Predictive model for important ground motion parameters associated with large and great earthquakes", U.S. Geological Survey Bulletin 1838.

14. Fukushima, Y., Tanaka, T. 1990, "A new attenuation relation for peak horizontal acceleration of strong earthquake ground motion in Japan", Bulletin of the Seismological Society of America 80: 757-783.

15. Grant-Taylor, T.L., Adams, R.D., Hatherton, T., Milne, J.D.G., Northey, R.D., Stephenson, W.R. 1974, "Microzoning for earthquake effects in Wellington", DSIR Bulletin 213.

16. Hayes, R.C. 1943, "Earthquakes in New Zealand during the year 1942", New Zealand Journal of Science and Technology 24: 191- 194.

17. Hays, W.W. 1980, "Procedures for estimating earthquake ground motions", U.S. Geological Survey Professional Paper 1114.

18. Idriss, I.M. 1990, "Response of soft soils during earthquakes", In Proceedings, Memorial Symposium to Honour Professor H.B. Seed. University of California at Berkeley: 273-289.

19. Idriss, I.M. 1985, "Evaluating seismic risk in engineering practice", $\underline{\text { In }}$ Proceedings, Eleventh International Conference on Soil Mechanics and Foundation Engineering. San Francisco: 255-360.

20. Joyner, W.B., Boore, D.M. 1981, "Peak horizontal acceleration and velocity from strong-motion records including records from the 1979 Imperial Valley, California, earthquake", Bulletin of the Seismological Society of America 71: 2011-2038.

21. Krinitzsky, E.L., Chang, F.K. 1988, "Intensity-related earthquake ground motions", Bulletin of the Association of Engineering Geologists 25: 425-435. 
22. Lowry, M.A., Ede, S.C., Harris, J.S. 1989, "Assessment of seismic intensities resulting from the 1987 Edgecumbe earthquake, New Zealand, and implications for modernising the intensity scale", New Zealand Journal of Geology and Geophysics 32: 145153.

23. New Zealand Seismological Observatory. 1992, Personal communication, Institute of Geological \& Nuclear Sciences.

24. Plafker, G., Galloway, J. 1989, "Lessons learned from the Loma Prieta, California, earthquake of October 17, 1989", U.S. Geological Survey Circular 1045.

25. Rynn, J.M.W., Brennan, E., Hughes, P.R., Pedersen, I.S., Stuart, H.J. 1992, "The Newcastle, Australia, earthquake: the facts and the misconceptions", Bulletin of the New Zealand National Society for Earthquake Engineering $252 ; 77-144$.

26. Seed, H.B., Romo, M.P., Sun, J.I., Jaime, A., Lysmer, J. 1988, "Relationship between soil conditions and earthquake ground motions", Earthquake Spectra 4: $687-730$.

27. Smith, W.D. 1992, Personal communication, Institute of Geo-logical \& Nuclear Sciences.

28. Smith, W.D. 1981, "The vast event - how vast how often? a statistical perspective of earthquake occurrence", In Large Earthquakes in New Zealand. The Royal Society of New Zealand Miscellaneous Series No. 5: $17-23$.

29. Smith, W.D., Berryman, K.R. 1986, "Earthquake hazard in New Zealand: inferences from seismology and geology", Royal Society of New Zealand Bulletin 24: 223-243.

30. Sritharan, S., McVerry, G.H. 1992, "Microzone effects in the Hutt Valley in records from a strong-motion accelerograph array", Bulletin of the New Zealand National Society for Earthquake Engineering (this volume).
31. Stephenson, W.R. 1991, "An assessment of the proportion of earthquakes likely to be amplified by flexible sediments", In Proceedings, Pacific Conference on Earthquake Engineering. Auckland, New Zealand: v. 3. p. $149-158$.

32. Stephenson, W.R., Barker, P.R. 1992, "Evaluation of sediment properties in the Lower Hutt and Porirua areas by means of cone and seismic cone penetration tests", Bulletin of the New Zealand National Society for Earthquake Engineering (this volume).

33. Taber, J.J., Smith E.G.C. 1992, "Frequency dependent amplifi-cation of weak ground motions in Porirua and Lower Hutt, New Zealand", Bulletin of the New Zealand National Society for Earthquake Engineering (this volume).

34. Tucker, B.E., King, J.L., Hatzfeld, D., Nersesov, I.L. 1984, "Observations of hard-rock site effects", Bulletin of the Seismological Society of America 74: 121-136.

35. U.S. Geological Survey Staff 1990, "The Loma Prieta, Califor-nia, earthquake: an anticipated event", Science 247: 286-293.

36. Van Dissen, R.J., Berryman, K.R., Pettinga, J.R., Hill, N.L. 1992, "Paleoseismicity of the Wellington-Hutt Valley segment of the Wellington fault, North Island, New Zealand", New Zealand Journal of Geology and Geophysics 35: 165-176.

37. Van Dissen, R.J., Berryman, K.R. 1991, "Timing, size, and recurrence interval of prehistoric earthquakes in the Wellington region, New Zealand", In Proceedings, Pacific Conference on Earthquake Engineering. Auckland, New Zealand; Vol. 3, p. 239249.

38. Wood, H.O. 1908, "Distribution of apparent intensity of San Francisco in the California earthquake of April 18, 1906", Report of the State Earthquake Investigation Commission, Washington, D.C., Carnegie Institute Publication 87: 220-245. 